\title{
PERAN SPIRITUALITAS TERHADAP KEMATANGAN KARIR PADA MAHASISWA UNIVERSITAS SEBELAS MARET SURAKARTA
}

\author{
Niken Fatimah Nurhayati \\ Fakultas Psikologi Universitas Diponegoro \\ niken.fatimah@gmail.com
}

\begin{abstract}
Abstrak. Penelitian ini bertujuan untuk mendapatkan bukti empiris tentang peran spritualitas terhadap kematangan karir pada mahasiswa UKM Olahraga UNS. Metode yang digunakan dalam pemilihan subjek proportional cluster sampling. Didapatkan subjek sejumlah 194 mahasiswa UKM Olahraga UNS. Pengukuran dilakukan dengan Skala Spiritual (Cronbach's a 0,864) dan Skala Kematangan karir (Cronbach's $\alpha$ 0,833). Hasil analisis data menggunakan regresi sederhana yang mendapatkan besaran sumbangan efektif spiritualitas terhadap kematangan karir sebesar 27,6\%. Besaran nilai koefisien korelasi rxy $=0.525$ dengan $\mathrm{p}<0.05$ menunjukkan adanya hubungan positif spiritual dengan kematangan karir. Semakin tinggi spiritualitas, semakin tinggi kematangan karir mahasiswa UKM Olahraga UNS.
\end{abstract}

Kata Kunci: Kematangan karir, mahasiswa, spiritualitas,UKM Olahraga UNS 


\section{Pendahuluan}

Menghadapi era globalisasi, tingkat persaingan di dunia kerja semakin ketat. Penting bagi mahasiswa untuk mempersiapkan karir dengan baik. Ketidaksiapan mahasiswa dalam merencanakan karir akan berdampak pada salah memilih pekerjaan atau bekerja tidak sesuai dengan bidang keahliannya. Realitas saat ini, tingkat penggangguran para sarjana yang di Indonesia masih cukup tinggi. Menurut data di Badan Pusat Statistik (2017) terdapat 618.758 tamatan perguruan tinggi yang tidak bekerja. Kondisi ini perlu mendapatkan perhatian yang lebih bagi perguruan tinggi untuk menyiapkan mahasiswa dalam menata karirnya.

Kematangan karir memiliki arti yang penting bagi mahasiswa. Individu dengan kematangan karier yang tinggi akan lebih memiliki inisiatif tinggi dalam melakukan pekerjaan, sehingga memungkinkan untuk pencapaian pekerjaan dengan lebih baik. Individu yang memiliki kematangan karir akan mampu melakukan tindakan yang terkait dengan : (a) perencanaan karir, (b) eksplorasi karir, (3) kekayaan informasi dan mampu mengambil keputusan. Studi yang dilakukan Liu, Peng, dan Wung (2014) pada 1202 anak muda berusia 16-29 tahun di Hongkong menemukan bahwa kematangan karir berhubungan positif dengan pencapaian pekerjaan seseorang. Hubungan tersebut akan semakin kuat apabila dikaitkan dengan faktor intrinsik yakni tingkat kecerdasan emosional dan minat. Sementara itu Lips-Wiersma (2002) menyatakan bahwa spiritualitas diakui sebagai hal yang penting dalam proses pengembangan karir. Hal ini juga diperkuat oleh pendapat Covey (2005) bahwa individu spiritualitas membantu individu memanfaatkan konsep diri dan kesadaran diri.

Spiritualitas berasal dari kata 'spiritus' yang artinya adalah nafas kehidupan (Nandaka, 2018). Spirit merupakan kekuatan yang tidak tampak yang memberikan nafas dalam kehidupan, menghidupkan dan memberikan energi. Spiritualitas menjadi bagian inti yang berperan terhadap keunikan individu dan menyatu dengan nilai-nilai transcendental yang memberikan makna, keterhubungan dan tujuan hidup, termasuk kematangan karirnya. Spiritualitas yang terdiri dari "tujuan, nilai, dan keyakinan yang secara individu berkomitmen untuk memberikan rasa, arah, makna, dan tujuan hidup" 
(Waterman, 2004). Wheeler, Ampadu, \& Wangari (2002) menjelaskan bahwa spiritualitas memiliki peran penting dalam membangun kesejahteraan.

Spiritualitas tidak dapat dihindari sebagai entitas dalam budaya (Tillich, 1956, 1983), dan dengan demikian dapat menjadi faktor yang mempengaruhi pengambilan keputusan dan pilihan karir (Awan \& Hussain, 2015). Spiritualitas memiliki fokus yang lebih luas, bukan hanya praktik keagamaan, tetapi juga menunjukkan tentang makna dan tujuan hidup di luar nilai material. Spiritualitas mencakup serangkaian makna yang mencakup aspirasi, kompatibilitas, visi, keyakinan, dan kebermaknaan kondisi. Di samping itu spiritualitas menjadi elemen yang tidak terpisahkan dari kehidupan manusia dan faktor yang memungkinkan manusia mengatasi berbagai tantangan (Tabei, Zarei, Joulaei,. 2016). Hardt, Schultz, Xander, Becker, dan Dragan (2012) menggunakan definisi dari Gall (2011) bahwa spiritualitas adalah keterhubungan dengan sesuatu yang lebih besar yang mengarahkan pada penciptaan makna kehidupan dalam diri individu. Lebih lanjut dijelaskan mengenai dimensi spiritualitas, yaitu: (a) percaya pada Tuhan, (b) pencarian makna, (c) mindfulness dan (d) perasaan aman.

\section{Metode Penelitian}

Penelitian ini merupakan penelitian korelasional yang bertujuan untuk mengetahui peranan spiritualitas terhadap kematangan karir pada mahasiswa UNS. Jumlah sampel dalam penelitian ini sebanyak 194 mahasiswa. Pengukuran dilakukan dengan Skala Spiritual (Cronbach's $\alpha$ 0,864) dan Skala Kematangan karir (Cronbach's $\alpha$ 0,833). Metode analisis data untuk mengetahui hubungan antara variabel spiritual dan kematangan karir menggunakan teknik uji regresi linear sederhana. Syarat-syarat/ asumsi-asumsi yang dipenuhi sebelum melakukan uji hipotesis yang menggunakan teknik regresi sederhana adalah normalitas data, outlier tidak mengganggu, linieritas data, multi-collinearity tidak ada diantara variabel prediktor, dan independent error. Perangkat lunak yang digunakan untuk analisis data berupa Microsoft Excel 2010 dan Statistical Package for Social Science (SPSS) versi 20.0. 


\section{Hasil Penelitian}

Setelah memenuhi uji asumsi normalitas dan liniearitas, dilakukan uji korelasi dengan teknik regresi linear sederhana. Didapatkan hasil terdapat hubungan yang positif dengan tingkat korelasi yang signifikan. Secara detail hasil dapat dilihat pada tabel 1 dan table 2 berikut ini:

Tabel 1 : Uji Korelasi Antara Spiritual Dengan Kematangan Karir

\begin{tabular}{|c|c|c|c|c|c|}
\hline \multicolumn{6}{|c|}{ Model Summary } \\
\hline Model & $\mathrm{R}$ & $\begin{array}{c}\mathrm{R} \\
\text { Square }\end{array}$ & $\begin{array}{c}\text { Adjusted R } \\
\text { Square }\end{array}$ & $\begin{array}{l}\text { Std. Error } \\
\text { of the } \\
\text { Estimate }\end{array}$ & $\begin{array}{l}\text { Durbin- } \\
\text { Watson }\end{array}$ \\
\hline 1 & $.525^{a}$ & .276 & .272 & 4.83111 & 1.772 \\
\hline
\end{tabular}

a. Predictors: (Constant), Spiritualitas

b. Dependent Variable: Kematangan_Karir

Terdapat hubungan positif antara spiritualitas dengan kematangan karir, artinya semakin tinggi spiritualitas, maka semakin tinggi kematangan karirnya, dan sebaliknya semakin rendah spiritualitas maka semakin rendah kematangan karirnya. Nilai R menunjukkan tingkat kekuatan hubungan antara variabel prediktor dengan variabel kriterium di tingkat sedang.

Besaran nilai koefisien determinasi (R2) adalah sebesar 0,276, maka dapat disimpulkan bahwa persentase sumbangan pengaruh yang diberikan variabel spiritualitas terhadap variabel kematangan karir adalah sebesar $27,6 \%$, sisanya $72,4 \%$ dipengaruhi oleh variabel lain.

Tabel 2: Uji Anova Antara Spiritualitas Dengan Kematangan Karir

\begin{tabular}{|c|c|c|c|c|c|c|}
\hline \multicolumn{7}{|c|}{ ANOVA $^{a}$} \\
\hline \multicolumn{2}{|c|}{ Model } & $\begin{array}{l}\text { Sum of } \\
\text { Squares }\end{array}$ & $\mathrm{df}$ & Mean Square & $\mathrm{F}$ & Sig. \\
\hline \multirow[t]{3}{*}{1} & Regression & 1705.901 & 1 & 1705.901 & 73.090 & $.000^{b}$ \\
\hline & Residual & 4481.212 & 192 & 23.340 & & \\
\hline & Total & 6187.113 & 193 & & & \\
\hline
\end{tabular}

a. Dependent Variable: Kematangan_Karir

b. Predictors: (Constant), Spiritualitas 
Berdasarkan Tabel 2 di atas, dapat diketahui nilai $\mathrm{F}$ adalah 73.090 dengan signifikansi $\mathrm{p}$ $<0,05$. Nilai $\mathrm{F}$ ini menggambarkan model yang digunakan dalam penelitian ini signifikan.

Tabel 3 : Analisis Persamaan Regresi

\begin{tabular}{|c|c|c|c|c|c|c|}
\hline \multirow{3}{*}{\multicolumn{2}{|c|}{ Model }} & \multicolumn{3}{|c|}{ Coefficients ${ }^{\mathbf{a}}$} & \multirow[b]{3}{*}{$\mathrm{t}$} & \multirow[b]{3}{*}{ Sig. } \\
\hline & & \multicolumn{2}{|c|}{$\begin{array}{l}\text { Unstandardized } \\
\text { Coefficients }\end{array}$} & \multirow{2}{*}{$\begin{array}{c}\text { Standardized } \\
\text { Coefficients } \\
\text { Beta }\end{array}$} & & \\
\hline & & $\mathrm{B}$ & Std. Error & & & \\
\hline 1 & (Constant) & 19.347 & 3.516 & & 5.503 & .000 \\
\hline & Spiritualitas & .465 & .054 & .525 & 8.549 & .000 \\
\hline
\end{tabular}

a. Dependent Variable: Kematangan_karier

Berdasarkan Tabel 3 di atas, dapat diketahui pada kolom B Constant (a) adalah 19,347 dan kolom B spiritualitas (b) adalah 0,465, sehingga diperoleh persamaan regresi yaitu $\mathrm{Y}=\mathrm{a}+\mathrm{bX}$ atau $\mathrm{Y}=19,347+0,465 \mathrm{X}$.

\section{Diskusi}

Hasil analisis data penelitian mengenai peranan spiritualitas terhadap kematangan karir menunjukkan bahwa terdapat hubungan positif dan signifikan antara spiritualitas dengan kematangan karir pada mahasiswa. Penelitian ini memberikan informasi bahwa peningkatan spiritualitas akan meningkatkan kematangan karir mahasiswa. Diperoleh nilai $\mathrm{R}$ sebesar 0,525 yang artinya bahwa hubungan antara spiritualitas dengan kematangan karir dalam tingkat sedang.

Spiritualitas sebagai fenomena psikologis dapat dilihat sebagai karakteristik seperti optimisme maupun kesejahteraan. Berdasarkan hasil empirik didapatkan hubungan yang signifikan spiritualitas dengan kematangan karir. Jika spiritualitas mempengaruhi kematangan karir, secara tidak langsung itu memiliki konsekuensi lain pada kehidupan individu. Literatur yang ada hampir mengabaikan peran spiritualitas dalam kematangan karir. Penelitian ini adalah upaya mengisi kesenjangan dengan mempelajari peran spiritualitas sebagai penentu kematangan karir. 
Penelitian ini memperkuat penelitian-penelitian sebelumnya yang telah dilakukan oleh Lips-Wiersma,( 2002) yang menyatakan bahwa spiritualitas diakui sebagai hal yang penting dalam proses pengembangan karir. Individu yang memiliki tingkat spiritualitas yang tinggi akan lebih baik dalam kematangan karirnya. Penelitian lain yang menguatkan peranan spiritualitas di dalam karir ditemukan mereka yang memiliki spiritualitas yang tinggi akan memiliki kepuasan kerja yang tinggi. Studi empiris yang menguatkan pendapat tersebut dilakukan oleh Azad Jammu \& Kashmir (dalam Clark, 1996, Jones et al., 2011) bahwa tingkat spiritualitas pada individu ditemukan secara positif mempengaruhi kepuasan kerja. Tingkat spiritualitas meningkatkan tingkat transendensi dan meningkatkan kesehatan mental pekerja, yang telah dibuktikan dalam literatur sebelumnya untuk meningkatkan kepuasan kerja. Studi lain yang terkait dengan spiritualitas dilakukan oleh Underwood dan Teresi (2002) yang menyatakan bahwa terdapat hubungan positif spiritual dengan varibel psikologis seperti optimisme. Penelitian lain menyebutkan bahwa individu yang memiliki optimisme yang tinggi akan memiliki pengetahuan yang lebih baik tentang karirnya (Creed, Patton, \& Bartrum, 2002). Individu dengan optimisme yang tinggi akan mampu menetapkan tujuan karir dengan baik sehingga memiliki pengetahuan terhadap perencanaan, eksplorasi, informasi, dan cara pengambilan keputusan karir yang tepat. Optimisme yang dimiliki akan mengarahkan individu melakukan upaya-upaya yang spesifik untuk mencapai tujuan karir. Di samping itu, spiritual juga mampu menguatkan aspek psikologis individu dengan menurunkan afek negatif akibat stres (Simoni dan Ortiz 2003). Atribut positif dapat mendorong seseorang meningkatkan kemampuan diri untuk mencapai tujuan karir yang telah ditetapkan (Avey, Luthans, \& Jensen, 2009). Dalam dunia kerja, individu yang memiliki spiritualitas yang tinggi akan memiliki daya juang yang tinggi dan tidak akan mudah menyerah pada kesulitan dan masalah yang dihadapi.

\section{Simpulan}

Berdasarkan hasil penelitian yang telah dilakukan pada 194 mahasiswa Universitas Sebelas Maret Surakarta yang mengikuti UKM Olahraga, maka simpulan dalam penelitian ini menunjukkan bahwa spiritualitas memiliki peran dalam kematangan karir mahasiswa UNS yang mengikuti UKM Olahraga. Sumbangan efektif spiritualitas 
terhadap kematangan karier sebesar 27,6 dan sisanya 72,4\% merupakan sumbangan dari faktor-faktor lain yang tidak diteliti dalam penelitian ini. Perlu diperhatikan keterbatasan penelitian ini bahwa ukuran sampel yang kecil, hasilnya tidak boleh digeneralisasikan. Meskipun, penelitian ini menemukan hubungan positif antara spiritualitas dan kematangan karir, tetapi ini tidak mungkin terjadi dalam semua situasi yang mungkin dapat mengubah hasilnya. Jadi, sangat disarankan bahwa peneliti selanjutnya harus menambahkan variabel lain untuk dilibatkan dalam penelitian ini.

\section{Daftar Pustaka}

Alvarez, G.M. (2008). Career Maturity a Priority for Secondary Education. Journal of Research in Educational Psychology, 6(3), 749-772.

Avey, J.B., Luthans, F., \& Jensen, S.M. (2009). Psychological Capital : A Positive Resource for Combating Employee Stress and Turnover. Human Resource Management, 48(5), 677-693.

Awan, A., Hussain S. N., 2015. Achieving Job Satisfaction through Spirituality: A Case Study of Muslim Employees. International Journal of Islamic Economics and Finance Studies, 2015, Year:1, Volume:1, Number:1

Badan Pusat Statistik. (2017). Pengangguran Terbuka Menurut Pendidikan Tertinggi yang Ditamatkan 1986-2017. Retrieved from https://www.bps.go.id.

Clark, Andrew and Oswald, Andrew. 1996. Satisfaction and comparison income, Journal of Public Economics, 61, 359-381

Covey, S. (2005). The 8th habit: From effectiveness to greatness. New York, NY: Free Press.

Creed, P., Patton, W., \& Bartrum, D. (2002). Multidimensional Properties of the LOT-R : Effects of Optimism and Pessimism on Career and Well-Being Related Variables in Adolescents. Journal of Career Assessment, 19, 42-61.

Lips-Wiersma, M. L. (2002). The influence of "meaning making" on career behavior. Journal of Management Development, 21, 497-520.

Liu, Y., Peng, K., Wong., C. (2014). Career Maturity and Job Attainment : The Moderating Roles of Emotional Intelligence and Social Vocational Interest. International Journal Education Vocational Guidance.

Nandaka, P.Moningka, C. 2018. Spiritualitas: Makna dan Fungsi. Buletin KPYN. Vol.4. No.4, Februari 2018. http://buletin.k-pin.org/index.php/arsip-artikel/244spiritualitas-makna-dan-fungsi 
Simoni, J. M., \& Ortiz, M. Z. (2003). Meditational models of spirituality and depressive symptomatology among HIV-positive Puerto Rican women. Cultural Diversity and Ethnic Minority Psychology, 9

Tabei, S.Z., Zarei, N,. Joulaei,. 2016. The Impact of Spirituality on Health. Shiraz EMed J. 2016 June; 17(6):e39053.

Tillich, P. (1983). Theology of culture (R. Kimball, Ed.). New York: Oxford University. Press. (Original work published 1956)

Underwood, L. G., \& Teresi, J. A. (2002). The daily spiritual experience scale: Development, theoreticaldescription, reliability, exploratory factor analysis, and preliminary construct validity using healthrelated data. Annals of Behavioral Medicine, 24(1), 22-33.

Waterman, A. S. (2004). Finding someone to be: Studies on the role of intrinsic motivation in identity formation. Identity, 4, 209-228.

Wheeler, E., Ampadu, L., \& Wangari, E. (2002). Lifespan development revisited: Spirituality throughout the life cycle. Journal of Adult Development, 9(1), 71-78. 